\title{
Knowledge of health care workers and ability of healthcare facilities in preventing of Ebola virus diseases/lassa fever in Benin
}

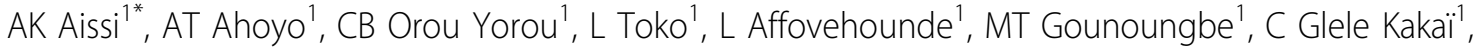 \\ DA Kinde Gazard ${ }^{2}$
}

From 3rd International Conference on Prevention and Infection Control (ICPIC 2015)

Geneva, Switzerland. 16-19 June 2015

\section{Introduction}

Benin republic, because of its geographical location, is threatened by the epidemic of the Ebola virus disease (EVD) that continues to plague in West Africa.

\section{Objectives}

Analyze the capacity of the health system in Benin relative to the axis of prevention of Viral Hemorrhagic Fevers.

\section{Methods}

Cross-sectional evaluative study from january to february 2015. Self-administered questionnaire to 418 health workers in all categories. They were from 52 health facilities identified in 08 of the 12 departments of Benin. Semi-structured interviews with health authorities responsibles of epidemiological and hospital hygiene matters. Direct observation of systems and existing procedures was made.

\section{Results}

$91 \%$ of workers know the early signs of EVD. $60 \%$ follow the news concerning Ebola in Africa. 28\% don't know the distinction between the EVD and the Lassa fever which an epidemic has been recently controlled successfully in northern Benin. 67\% know the EVD transmission modes. $42 \%$ didn't know the incubation period for EVD, and $81 \%$ know how to identify a suspected case. $87 \%$ are convinced that there is no cure treatment even in african medicine. 94\% admit that awareness raising currently underway on Ebola improve the awareness in

${ }^{1}$ Direction Nationale la Santé Publique, Benin

Full list of author information is available at the end of the article applying hospital hygiene guidelines. $91 \%, 43 \%, 42 \%$ and $39 \%$ respectively know that the Ebola virus may be neutralized by bleach, alcohol at $70^{\circ}$, ultraviolet light and formol. $81 \%$ assume that hand hygiene solutions are an effective way to prevent and control infections, but its supply in care services is uncommon or irregular. 51\% of responsibles think that the alcohol-based handrub dispensers are expensive and in absence of subsidies or grants, their purchase could lead to significant extra costs for patients. The Methods of treatment of biomedical waste are not performing with a disparity depending on the size of care facilities.

\section{Conclusion}

The capacities of the hospital system in Benin are underperforming for the prevention of EVD and Lassa fever. Infection prevention and control strategies must be implemented in the short term for the safety of patients and staff.

\section{Disclosure of interest}

None declared.

\section{Authors' details \\ ${ }^{1}$ Direction Nationale la Santé Publique, Benin. ${ }^{2}$ ministère de la Santé,} Cotonou, Benin.

Published: 16 June 2015

doi:10.1186/2047-2994-4-S1-P4

Cite this article as: Aissi et al: Knowledge of health care workers and ability of healthcare facilities in preventing of Ebola virus diseases/lassa fever in Benin. Antimicrobial Resistance and Infection Control 2015

4(Suppl 1):P4.
C Biomed Central

(c) 2015 Aissi et al; licensee BioMed Central Ltd. This is an Open Access article distributed under the terms of the Creative Commons Attribution License (http://creativecommons.org/licenses/by/4.0), which permits unrestricted use, distribution, and reproduction in any medium, provided the original work is properly cited. The Creative Commons Public Domain Dedication waiver (http:// creativecommons.org/publicdomain/zero/1.0/) applies to the data made available in this article, unless otherwise stated. 